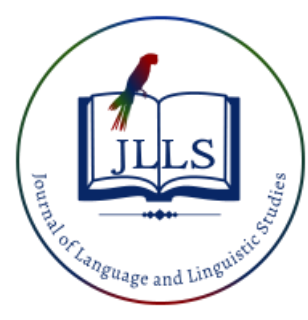

Available online at www.jlls.org

JOURNAL OF LANGUAGE

AND LINGUISTIC STUDIES

ISSN: $1305-578 \mathrm{X}$

Journal of Language and Linguistic Studies, 17(2), 755-766; 2021

\title{
Objectives of teaching English skills and their assessment in Indian schools: A
}

\section{study on the divergence}

\author{
Nida Qayoom $^{\text {a iD }}$, Mohammad Saleem ${ }^{\text {b } 1 \text { iD, Mozaffar Mansoor }}{ }^{\text {c iD }}$ \\ ${ }^{a}$ King Abdulaziz University - Rabigh branch, Rabigh Saudi Arabia \\ ${ }^{b}$ King Abdulaziz University - Rabigh branch, Rabigh Saudi Arabia \\ 'Imam Abdulrahman Bin Faisal University, Dammam, Saudi Arabia
}

\section{APA Citation:}

Qayoom, N., Saleem, M., \& Mansoor, M. (2021). Objectives of teaching English skills and their assessment in Indian schools: A study on the divergence. Journal of Language and Linguistic Studies, 17(2), 755-766. Doi: 10.52462/jlls.53

Submission Date:22/02/2021

Acceptance Date:10/05/2021

\begin{abstract}
Listening and speaking are active language skills and need special attention in English language pedagogy, especially in ESL/EFL contexts. English in India is taught as a second language in almost all the states, and the secondary education boards stipulate the teaching of all the four language skills as the objective of teaching English, yet the teaching and assessment system is only read-write intensive, and the active language skills, i.e., listening and speaking, are neglected in teaching as well as in assessment. The present paper is the result of a survey of the language teaching objectives, learning outcomes and assessment policies of two secondary education boards in India to investigate whether there exists any divergence between the stated objectives regarding teaching English language skills, and the testing pattern followed. The findings of the study suggest that there exists a divergence between the objectives stated by state level secondary education boards and their assessment patterns set for the English language. The study recommends that there should be a uniform standard of teaching and assessment of English in secondary schools in India, and there should be more research studies on the potential negative impact of the neglect of teaching and assessment of active language skills.
\end{abstract}

Keywords: English assessment; ELT in Indian schools; skills needs; objectives of ELT in India; divergence between objectives and skills tested

\section{Introduction}

English enjoys the status of being the second language in most of the states in India, as notes Meganathan (2011, p. 26), "English is offered as a second language in 19 states, of which 16 introduce it in Class I, one in Class III and two as late as Class V." In school curricula, all the four language skills, namely, listening, speaking, reading and writing, are given equal importance, and defined as such in the objectives of teaching English to students as can be gleaned from the objectives of teaching English at secondary stage spelt out in the Learning Outcomes for the English Language, published by NCERT, i.e. the National Council of Educational Research and Training (NCERT, 2019). The primary learning outcome for the English language for secondary school students is moderately good fluency

\footnotetext{
${ }^{1}$ Corresponding author.

E-mail address: msshareef@kau.edu.sa
} 
in spoken and written English. To achieve the main objectives of teaching English at this stage, central as well as state school boards prescribe extensive reading and writing materials, including fictional as well as non-fictional writing. But this strategy helps develop only the passive linguistic competencies. At the end of the term, students are tested in the same competencies. The active linguistic competencies are neither taught using authentic materials nor assessed in the term-end exams (Ramanathan, 2007). The researcher argues that imparting and assessment of active linguistic competencies are neglected in India for such factors as large classes, teachers' inadequate command of English, and the lack of easy access to support materials and facilities. Since there is no provision for testing the students' proficiency in the active skills, there is no provision for their formal teaching either. At the most, the task is left to the discretion of the concerned teachers. For instance, Chikkala (2018, p. 6) notes that, "Oral linguistic assessment had no value in India. But now the idea has been introduced because of employability, for employers seek candidates with good communication skills, especially spoken English." But, still there are no uniform principles for the appraisal of learners' spoken English. In fact, there are no standard criteria for teaching of English either, and the so-called "English-medium schools" mushrooming in India offer only low quality education in English, as Endow $(2018$, p. 1) notes in her study. In Endow's opinion, students do lack competence in English, and it goes unnoticed at the primary level. The researcher warns that the low learning achievement for English among the products of such schools impacts learning in other subjects also negatively. The issue gets complicated since education in other subjects is imparted in English, their textbooks are in English and exams in the concerned subjects are also conducted in English. It is difficult for children to comprehend what they read, while no one pays attention to their inability to communicate in English.

The fallout of this oversight is that there exists a huge divergence between the objectives stated for the teaching of English skills to students and the tests conducted to ascertain whether the stated objectives have been achieved, or not. One potential unwanted consequence of this situation may be that Indian learners generally lag behind in the active use of English, though most of them attain a fairly good competence in the use of passive skills (the observation is a mere presumption of the researchers, not based on research since presently there are no research studies on the potential association between the lack of teaching/testing of the active English skills and students' general failure to achieve desired competence in the skills in Indian contexts). The present study has been motivated by the urgent need to address the discrepancy between the objectives of teaching the four English language skills to secondary students in India and the lack of testing provision for the two active skills- listening and speaking.

\section{Research Problem}

The two Indian school boards for secondary education in India, namely, the Central Board of Secondary Education (CBSE), and the respective state secondary education boards (e.g., Uttar Pradesh Board of Secondary Education in the state of Uttar Pradesh) prescribe teaching of English as a second language with the aim of students acquiring good competence in all the four language skills. But, in actual practice, the study syllabi outlined by different school education boards are reading and writing intensive, and largely ignore listening and speaking skills, in classroom teaching as well as in the summative assessment of the skills for grading/certification (Agnihotri, 2001; Chikkala, 2018; Daswani, 2001; Endow, 2018; Ramanathan, 2007). Thus, there is a divergence between the skills in English students are expected to master as an outcome of the courses of study and the official certification of the desired skills through summative assessments. This is a significant issue that needs urgent attention since there is a probability that lack of formal instruction and assessment of listening and speaking skills in English must have been affecting the oral comprehension of English of students 
passing out of schools (further research is the need of the time on the relationship between the skills students are supposed to possess at the end of secondary school education in English and the way some skills are tested, or not tested at all. Research studies may be conducted on the failures/problems of Indian students in listening and speaking tests for international English proficiency tests, such as IELTS and TOEFL [and GRE, to a large extent. Though GRE is not a language proficiency test, still it measures skills important for graduate and professional education at institutions where the language of instruction is English, and therefore, it requires a very high proficiency in English]. The researchers presume that students studying under U.P. Board specifically face problems in listening and speaking tests in English). On a careful scrutiny of the existing research literature on the subject, the researchers note that there are no research works in this area in the Indian context yet.

A related, relevant question to ask is how are listening and speaking skills prescribed (or not prescribed) to be taught to secondary school students to whom these active skills are very important, for a large number of these students join universities/vocational institutes for higher education where, in most cases, the medium of instruction is English. Is there a standard, uniform policy/method followed in schools to teach the skills or, is it left to the discretion of concerned teachers? In state boards, such as U. P. Secondary Education Board, the teaching of listening and speaking in English is not prescribed, and as a result, the skills are not examined at the end of the session. CBSE has introduced the teaching and testing of the skills in the last decade (from 2013 on), but the practice is not yet standardized, especially as regards the teaching of speaking and listening skills.

\section{Literature Review}

\subsection{Listening and speaking as constructs}

It would be helpful to be clear on what we mean by 'listening and speaking' in this paper, and be apprised of scholarly opinions on the skills as research constructs, before we embark on a critique of the lack of development of these skills among secondary students in India. Language researchers have defined the construct "listening comprehension" in various ways. For example, the communicative listening scholars Brown and Yule (1983, p. 58) say that in foreign language teaching scenarios, listening comprehension is taken to mean the listener's capacity to repeat the text. If the listener can learn the text as he heard it, "he would probably be said to have understood it." The authors are not very happy with this supposition though. According to Nadig (2013), listening comprehension is not just grasping the meaning in spoken language but it refers to the host of processes involved in grasping that meaning. These processes are recognition of different sounds in speech, comprehending word meanings, and, at the same time, making sense of the sentence syntax. To Rost (2002, p. 77), listening comprehension is a process in which listeners interact with each other and "construct meaning." Rost (2002, p. 154) says that in listening comprehension segmental as well as supra-segmental features, such as distinct sounds, previous knowledge, grammatical structures, stress, pitch and intonation, and the other "linguistic or non-linguistic clues" are as important as the meaning. On the other hand, Dirven and Oakeshott-Taylor (1984, p. 326) consider listening comprehension to be just another aspect of applied linguistics research in which the focus of attention is on comprehension of speech and the features of foreign language speaker's utterance in an attempt to mark its distinctive quality. Buck (2001, p. 114) defines the listening construct (which he calls "default listening construct") as the learners' capability to comprehend native speakers' language in real time. To Buck (2001), foreign language learners must also be able to fully comprehend the linguistic information coded in written texts so that they can make out the implied meaning of the given text. In the present paper, by 'listening comprehension' the researchers have adopted Buck's (2001) definition of the construct and study it as students' competence to understand the native speaker's speech input, or what they hear. 
Buck's (2001) definition of the construct 'listening comprehension' is based on competency, and not on context. Accordingly, for the present research, the context hasn't been taken into consideration, except that in the Indian context, the teachers, as well as learners, are non-native speakers. Although they may not be highly accented, yet the listening comprehension samples used for English language tests, such as TOEFL and IELTS are from native speech.

The construct of speaking, in the case of a second language speakers, is seen as their communicative competence, based on their grammatical knowledge, phonological knowledge and pragmatic knowledge of the target language (see Plough, 2018). Linguists consider testing of speaking skills quite problematic, for various reasons. For instance, Fulcher (2003, p. 181) notes that testing of speaking in second/foreign language teaching gained acceptance quite late - in the 1970s in the US - in the academia. The author considers that there are several issues underlying speaking tests, the major one being that the construct "speaking" is difficult to define since pronunciation, intonation, accuracy, fluency, use of speaking strategies, as well as pragmatic interaction, all are important aspects of speech, and therefore, "The problem is that in the course of a normal conversation, all of these aspects are important."

\subsection{Listening and speaking: Neglected areas of research and teaching/testing}

Learner competence in listening and speaking in English, and its testing in exams, is a comparatively neglected field in schools in India, and the situation answers for the general neglect of research and scholarly intervention in these skills in native as well as non-native settings. Bozorgian (2012, p. 657), for instance, comments that, "Whilst a substantial amount of research has been conducted in reading and writing skills, investigators have underscored the role of listening skill in human learning and development." Buck's (2001) opinion is that due to some practical complexities, listening skill is not paid due attention to in several foreign language teaching contexts. Osada (2004) also expresses similar concerns and regrets that since listening skill is considered a passive linguistic skill, it lacks acceptance in academic circles as demanding attention and the general idea is that the skill develops without help. In second language teaching contexts, both teachers, as well as learners, place the least significance on listening. As a result, listening and speaking pedagogy suffers in nonnative settings and sets a bad precedence for foreign language pedagogy.

Nevertheless, scholars (e.g., Bozorgian, 2012; Buck, 2001; Graham, 2006; Hunsaker, 1990; Morley, 2001; Morris \& Leavey, 2006; Munro \& Derwing, 1999; Rost, 2001; Rubin, 1994; Underwood, 1989; Vandergrift, 2007) opine that listening comprehension is "one of the most significant skills" in second language learning (Buck, 2001, p. 32) since it is directly associated with the development of other skills. These scholars accord the highest significance to listening. They argue that listening is the most useful skill to foreign language learners and in comparison to reading and writing, listening skill takes less time to develop. Moreover, listening skill makes the development of other language skills easy. Research has shown that improvement in listening skills leaves a positive impact on other language skills - reading, writing, and speaking. To illustrate the point, Morris and Leavey (2006) conducted an experimental study with preschool children, focussed on phonological development among them through early listening. Their results showed the promise of improvement in preschool children's phonological awareness through listening. To emphasize the significance of listening skill, Buck (2001, pp. 32-47) draws on the similarities between reading and listening, but lays more stress upon the uniqueness of listening, the important characteristics of spoken texts being "phonological modification, accent, prosodic features (stress, rhythm, intonation), speech rate, hesitation phenomena, discourse structure, and non-verbal signals." In the opinion of Vandergrift (2007, p. 191), "listening comprehension lies at the heart of language learning, but it is the least understood and least researched skill"... and "the process of listening needs more research attention 
with in-depth studies that probe deeper into the interaction of the processes and factors that influence successful L2 listening."

\subsection{Speaking/listening difficulties}

Problems related to listening comprehension and its testing at adult learning centres in EFL contexts seem to be worldwide phenomena. For example, in Saudi Arabian contexts, English learners face serious problems in listening skill since grammar, reading, and vocabulary are given more weightage in teaching over listening and speaking. Units on listening and speaking are covered in course books only marginally, and therefore, teachers do not give significant time to teach these skills (Hamouda, 2013). Hasan (2000) reports from Damascus University that a number of EFL learners at the university find it extremely difficult to comprehend English spoken at a normal speed. The researcher looks particularly at learner strategies, features of the listening text, and the attitude of the listener. Similarly, Graham's (2006, p. 165) findings in her study of English students learning French are that the language element her students are the least successful in is listening comprehension. The researcher reports that text delivery speed, distinguishing individual words in connected speech, and comprehension of the meaning of words spoken in context were the major issues her learners faced. Speaking skill is not easy to acquire either. Olfaz (2019) observes that one of the factors hampering foreign language learners' competence is anxiety. Eraslan (2018), on the other hand, with reference to simultaneous interpretation, notes that sentence length and sentence complexity play an important role in speech comprehension for a foreign language learner. (p. 150).

In the area of language testing, assessment of listening abilities is the most significant part, and yet the least attention is paid to this area of language assessment, and researchers are still unclear on the parameters and paradigms of the field (Alderson \& Bachman, 2001). It must be noted that the assessment of listening comprehension bears a significant impact on curriculum design, pedagogy practices, and learning behaviour development. Teaching as well as testing of listening comprehension needs to be sensitive to factors, such as second/foreign language learners' cultural differences from the target language, accents (British, American, and Canadian), complex and unfamiliar lexical items in native speech, longer sentences, complex syntax, slangs, fast speech, etc. Supra-segmental features in native speech, such as accent, pitch and intonation, bear the potential to make the speech incomprehensible to foreign language learners (Munro \& Derwing, 1999), although the researchers added that prosodic errors appear to be a more potent force in the loss of intelligibility than phonetic errors. In Vandergrift and Goh's (2009) opinion, a large section of second/foreign language learners finds a native speaker's accented speech very difficult to comprehend since "texts and utterances need to be interpreted in their wider communicative contexts" (p. 399) while second/foreign language learners learn the target language commonly in created contexts. Buck $(2001$, p. 35) indicates that when listeners hear an unfamiliar accent, they face problems which may "disrupt the whole communication process." Underwood (1989) considers speed as one of the factors making listening passage difficult, while Graham (2006, pp. 171-173) also found the speed of delivery a prominent factor. The other significant factors affecting foreign language learners' listening comprehension are a limited vocabulary at their disposal, poor syntax competence, and misinterpretations about listening tasks. Bloomfield et al. (2010), Hasan (2000), Vandergrift (2007), Walker (2014), and Yagang (1994) are in agreement with Graham's Observation. For example, Bloomfield et al. $(2010$, p. 1) say that a number of factors affect second language learners' listening skill, such as lack of enough exposure to the target language, lack of familiarity with and inability to understand the non-native language's phonology, limited vocabulary, and lack of knowledge on the "topic, text, structure, schema, and culture." Pronunciation of words by native speakers poses a serious challenge to foreign language learners' listening comprehension and since there are dramatic changes in the acoustics involved in 
spoken words, learners often fail to associate the spoken words with the written text (Walker, 2014). In the same manner, Yagang (1994, p. 1) observes that, "The evidence that shows why listening is difficult comes mainly from four sources: the message to be listened to, the speaker, the listener, and the physical setting." Boyle (1984), Teng (2002), and Zhang (2009) have similar observations, found in agreement with the factors noted by Yagang (1994), associated with listeners, speakers, stimulus, and context.

\subsection{Assessment of listening/speaking}

Despite all the above-mentioned difficulties, issues, problems, and challenges, assessment of speaking and listening (ASL) in English is essential for secondary students, before they join universities and vocational institutes. In India, the Central Board of Secondary Education (CBSE), has taken the initiative in this regard and introduced ASL in their exams from 2013 (Ahmad \& Agarwal, 2018, p. 13). But the state secondary education boards in India still do not formally test the active skills. CBSE has also realized, as we have also noted in the views of scholars in the review of literature section, that testing of these active skills necessitates teachers to specifically pay extra attention to the skills in their regular teaching, and students to practice them on a regular basis (CBSE, 2013, p. 3). But, though CBSE has started assessment of speaking and listening skills, ${ }^{i}$ there is no standard provision for teaching the skills in the classroom, and therefore, the teaching is left to the discretion of concerned teachers, to devise the ways and means to develop the skills among their students.

\section{Research Questions}

Keeping in view the identified research problem, and the opinions of English language educationists on the essentiality of teaching and testing of speaking and listening competence skills to second/foreign language learners, the present research study has been designed to find answers to the following questions:

RQ 1: Is there a divergence between the objectives of teaching English language skills to secondary school students in India and the teaching as well as testing of the active skills?

RQ 2: Should teaching and testing of active language skills in English, viz., speaking and listening, to secondary students be made mandatory by school boards in India?

\section{Aims and Objectives of the Present Research}

The current study was started with two objectives in view. The primary objective of the study was to identify the gap between the prescriptive objectives of teaching English language skills to secondary school students in India and the teaching as well as end-of-term testing of active skills, i.e., speaking and listening. The secondary objective of the study was to argue and make a case that listening and speaking must form part of English pedagogy and examination by the state level secondary education boards (e.g., U.P. Board of Secondary Education) in the Indian school system.

\section{Research Method}

The current research has been primarily based on a survey of the literature, and an objective evaluation of the data collected through the literature survey. The primary literature surveyed for data collection included (i) The curricular objectives literature of the two secondary education boards in India, viz., CBSE, and state boards (e.g., U.P. Board of Secondary Education), (ii) CBSE/U.P. Board 12th class English question papers of the last 5 years, and (iii) CBSE directive on assessment of speaking and listening. 
The secondary source of data collection for the study has been the relevant research articles, research works in the area, and other suitable materials, such as books published globally in the area of teaching and assessment of speaking and listening skills in English.

\section{Data Analysis}

Analysis of data collected from curricular objectives literature from the secondary education boards (CBSE/State Secondary Education Boards) shows that the secondary education boards prescribe that the four linguistic skills (LSRW) should be taught to secondary students, with the intent of developing learners' working knowledge in English, which amounts to learners having a good proficiency in the language. But, the prevalent classroom teaching practices are read-write intensive since there are no clear guidelines on the teaching of speaking and listening. It is only CBSE that has started conducting speaking and listening skills assessment from 2013 onwards, which has prompted the teaching of these active skills in the classroom, whereas the state boards have no provision, either for the pedagogic practice or for examination of the active linguistic skills. The end of term examination for the English language in the U.P. Board, for instance, comprises of written examination that tests only passive linguistic skills. The 100 marks test paper consists of reading comprehension passages, questions on grammar, composition, translation, sentence structure, vocabulary knowledge, and memory retention. No test was conducted to assess speaking and listening, so no marks were allotted for the skills. CBSE end of term written exam is also focused on reading, writing, and memory retention. However, out of 100, the written exam is allotted 80 marks and 20 marks are allotted for ASL. The summarized exam patterns followed by the two boards are presented in Table 1 given below:

Table 1. Summary of secondary school end-of-term exam pattern and allotment of marks: U. P. Board and CBSE

\begin{tabular}{|c|c|c|c|}
\hline Board & Examination Paper & Contents & Marks allotted \\
\hline \multirow[t]{10}{*}{ U. P. Board } & Section A & Prose passage & 50 \\
\hline & & Poetry & \\
\hline & & Play & \\
\hline & & Short Stories & \\
\hline & & Figures of Speech & \\
\hline & Section B & General English & 50 \\
\hline & & Vocabulary & \\
\hline & & Translation & \\
\hline & & Essay Writing & \\
\hline & & Unseen Passage & \\
\hline \multirow[t]{6}{*}{ CBSE } & Section A & Reading & 30 \\
\hline & Section B & Advanced Writing Skills & 30 \\
\hline & Section $\mathrm{C}$ & Literature & 20 \\
\hline & & (reading and memory-based) & \\
\hline & ASL & Part A: Speaking & 10 \\
\hline & (for class $9,10,11)$ & Part B: Listening & 10 \\
\hline
\end{tabular}




\section{Results}

Analysis of the collected data reveals that there is a clear divergence between the objectives of teaching English language skills to secondary students in India and the teaching as well as assessment of the active language skills, i.e., speaking and listening. The situation must be impacting the students negatively since the students may be facing huge problems at university/vocational education courses as the higher studies in India are prescribed to be conducted in the medium of English to meet the international higher education standards. The obtained results are summarized in table 2, below:

Table 2. Summary of results

\begin{tabular}{llllll}
$\begin{array}{l}\text { School } \\
\text { Board }\end{array}$ & $\begin{array}{l}\text { English language } \\
\text { skills prescribed }\end{array}$ & $\begin{array}{l}\text { Objectives of teaching } \\
\text { prescribed skills }\end{array}$ & Teaching & Assessment & $\begin{array}{l}\text { Divergence } \\
\text { in Objectives } \\
\text { and teaching } \\
\text { /assessment }\end{array}$ \\
\hline $\begin{array}{l}\text { State } \\
\text { Education } \\
\text { Boards }\end{array}$ & Listening & To develop listening skill & No guidelines & No guidelines & Yes \\
& Reaking & To develop speaking skill & No guidelines & No guidelines & \\
& Writing & To develop reading skill & Yes & Yes & \\
\hline CBSE & To develop writing skill & Yes & Yes & \\
& Speaking & To develop listening skill & Yes & Yes & No \\
& Reading & To develop reading skill & Yes & Yes & \\
& Writing & To develop writing skill & Yes & Yes &
\end{tabular}

The information can be graphically presented as in figure 1 given below:
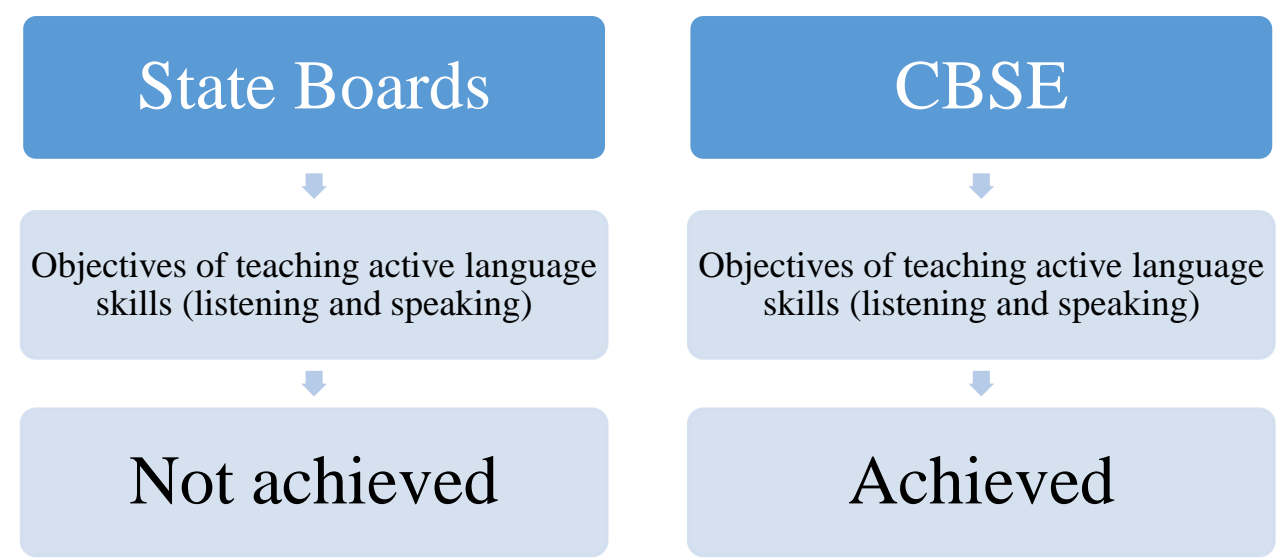

Figure 1. Graphical representation of divergence in objectives and teaching/assessment of active English language skills in Indian secondary school boards

\section{Research Findings}

The following conclusions can be safely drawn from the analysis of the research data:

(I) There is an obvious divergence between the objectives of teaching English language skills to secondary school students in India and pedagogic practice and testing of competence in the active linguistic skills. 
(II) In second/foreign language contexts, teaching and testing of English speaking and listening skills to school students are highly recommended by researchers and established educationists. Therefore, it is required that the teaching and assessment of these active skills be made mandatory in the Indian school system as well.

\section{Conclusions}

The current study was taken up to find answers to two research questions, one on divergence and the other on recommendations to make pedagogic practice and evaluation of English speaking and listening skills mandatory for senior secondary students in India. Findings from the research answer both the research questions in the affirmative. Out of the two secondary education boards in India, only one board has adopted the pedagogic practice and evaluation of speaking and listening skills for senior secondary students. The prevalent socio-economic factors world over, such as the market forces, employability, globalization, upward social mobility and better job opportunities in the domestic as well as international job market (see Dahlman, 2010) have brought in sufficient pressure in India to force secondary education establishments to teach and assess all the four language skills to better equip their products to face the real world situations. English is adopted as a second language in Indian education. Therefore, it is highly recommended that the state level secondary education boards which teach and assess only the passive language skills, i.e., reading and writing, also make the teaching and assessment of speaking and listening mandatory for secondary school students, and thus, bridge the gap between their stated objectives and the actual practice as regards teaching and assessment of active English language skills to their students.

\subsection{Significance of the present research}

The current research is a timely intervention in the theory and praxis of English language teaching in India. It is very significant as a theoretical document since there are almost nil research studies on this topic in Indian contexts. There are no research studies on a potential link between the lack of teaching/testing of the active English skills and students' general failure to achieve desired competence in the skills in Indian contexts either. It is hoped that further research studies will be taken up to explore both these research areas. The study is significant as a document on the praxis of teaching English in India since teaching and assessment of active English language skills- speaking and listening - are ignored by state secondary education boards which may have been impacting students' competence in English skills negatively. If the two skills are assessed at the end of the secondary school term, the teaching of those skills will become a necessity.

\subsection{Limitations of the study and recommendations for further research}

Attempts have been made to be as thorough as possible with the data collection, analysis, and documentation of the present study, yet certain limitations might have impacted the findings. First of all, researchers and educationists in India have largely ignored this area of English language teaching, resulting in a paucity of studies on the subject. The situation proved to be a limitation since the findings of the present study could not be evaluated and judged from a comparative perspective for the same reason. The second limitation noted was that there are no studies exploring any possible negative impacts of the lack of pedagogic practice and testing of speaking and listening skills on the second language competence of secondary school students in India, especially the products of state education boards, that might have affected their scores at international English language proficiency tests, such as IELTS and TOEFL (and GRE). 
Thus, the researcher recommends further research studies on (i) the possible impacts of the lack of teaching and evaluation of English speaking and listening competence building in senior secondary students in state education board schools on their English proficiency building in English, and (ii) the potential link between the lack of pedagogic practice and evaluation of speaking and listening competence building in senior secondary students and their performance in international English language proficiency tests, such as IELTS and TOEFL (and GRE).

\section{References}

Agnihotri, R. K. (2001). English in Indian education. In C. J. Daswani (Ed.), Language education in multi-lingual India (pp. 186-209). New Delhi: UNESCO

Ahmad, K., \& Agarwal, P. (2018). The role of CBSE ASL in enhancing the speaking and listening skills of students. In A. Keedwell (Ed.), Explorations: Teaching and Learning English in India, Issue 8: Assessing learning (2) (pp. 13-28). Kolkata: British Council

Bloomfield, A., Wayland, S. C., Rhoades, E., Blodgett, A., Linck, J., \& Ross, S. (2010). What makes listening difficult? Factors affecting second language listening comprehension (Technical Report TTO 81434 E.3.1). College Park, MD: University of Maryland Center for Advanced Study of Language. Retrieved on February 22, 2021 from: https://apps.dtic.mil/sti/pdfs/ADA550176.pdf

Boyle, J. P. (1984). Factors affecting listening comprehension. ELT Journal, 38(1), 34-38. DOI: 10.1093/elt/38.1.34

Bozorgian, H. (2012). The relationship between listening and other language skills in International English Language Testing System. Theory and Practice in Language Studies, 2(4), 657-663. DOI: 10.4304/tpls.2.4.657-663

Brown, G., \& Yule, G. (1983). Teaching the spoken language (Vol 2). Cambridge: Cambridge University Press.

Buck, G. (2001). Assessing listening (Cambridge Language Assessment). Cambridge: Cambridge University Press. DOI: 10.1017/CBO9780511732959

CBSE. (2013). Assessment of speaking and listening skills: Guide for teachers. Retrieved on February 22, 2021 from: http://cbseacademic.nic.in/web_material/ASL/2013/2.\%20ASL\%20Guide\%20for\%20Teachers.pdf

CBSE. (n.d.). CBSE ASL corner. Retrieved on February 22, 2021 from: http://cbseacademic.nic.in/aslcorner.html

CBSE. (2020). CBSE Secondary Curriculum 2020-21 (Volume I Main Subjects). Retrieved on February 22, 2021 from: http://cbseacademic.in/web_material/Curriculum16/Secondary/Secondary\%20School\%20Curricul um\%20Vol\%201.pdf

Chikkala, S. (2018). Current oral language assessment in professional colleges and its impact on student performance. In A. Keedwell (Ed.), Explorations: Teaching and learning English in India. Issue 8: Assessing learning (2) (pp. 6-14). Kolkata: British Council.

Council of Europe. (n.d.). Common European framework of reference for languages: Learning, teaching, assessment (CEFR). Retrieved on February 22, 2021 from: https://rm.coe.int/16802fc1bf

Dahlman, C. J. (2010). Education and growth of services. In E. Ghani (Ed.), The service revolution in South Asia (pp. 261-312). New Delhi: Oxford University Press. 
Daswani, C. J. (Ed.). (2001). Language education in multi-lingual India. New Delhi: UNESCO.

Dirven, R., \& Oakeshott-Taylor, J. (1984). Listening comprehension (Part I). Language Teaching, 17(4), 326-343. DOI: 10.1017/S026144480001082X

Endow, T. (2018). Inferior outcomes: Learning in low-cost English-medium private schools - A survey in Delhi and National Capital Region. Indian Journal of Human Development, 12(1), 1-19. DOI: $10.1177 / 0973703018779725$

Eraslan, S. (2018). The impact of sentence length and complexity on fluency in Turkish-English simultaneous interpreting. Journal of Language and Linguistic Studies, 14(3), 145-153. Retrieved on March 13, 2021 from: https://www.jlls.org/index.php/jlls/article/view/914/396

Fulcher, G. (2003). Testing second language speaking. New York: Routledge.

Graham, S. (2006). Listening comprehension: The learners' perspective. System, 34(2), 165-182. DOI: 10.1016/j.system.2005.11.001

Hamouda, A. (2013). An investigation of listening comprehension problems encountered by Saudi students in the EL listening classroom. International Journal of Academic Research in Progressive Education and Development, 2(2), 113-155.

Hasan, A. (2000). Learners' perceptions of listening comprehension problems. Language, Culture and Curriculum, 13(2), 137-153. DOI: 10.1080/07908310008666595

Hunsaker, R. A. (1990). Understanding and developing the skills of oral communication: Speaking and listening $\left(2^{\text {nd }}\right.$ ed.). Englewood, CO: J. Morton Press.

Meganathan, R. (2011). Language policy in education and the role of English in India: From library language to language of empowerment. In H. Coleman (Ed.), Dreams and realities: Developing countries and the English language (pp. 57-86). London: British Council. Retrieved on February 22, 2021 from: https://www.teachingenglish.org.uk/sites/teacheng/files/Z413\%20EDB\%20Section04_0.pdf

Morley, J. (2001). Aural comprehension instruction: Principles and practices. In M. Celce-Murcia (Ed.), Teaching English as a second or foreign language (pp. 69-85). Boston: Heinle and Heinle.

Morris, T., \& Leavey, G. (2006). Promoting phonological awareness in nursery-aged children through a Sure Start Early Listening programme. International Journal of Early Years Education, 14(2), 155-168. DOI: 10.1080/09669760600661559

Munro, M. J. \& Derwing, T. M. (1999). Foreign accent, comprehensibility and intelligibility in the speech of second language learners. Language Learning, 49(1), 285-310. DOI: 10.1111/00238333.49.s1.8

Nadig, A. (2013). Listening comprehension. In F. R. Volkmar (Ed.), Encyclopedia of autism spectrum disorders. New York: Springer. DOI: 10.1007/978-1-4419-1698-3_349

NCERT. (2019). Learning outcomes at the secondary stage. New Delhi: Publication Division, NCERT. Retrieved on February 22, 2021 from: https://www.ncert.nic.in/pdf/notice/learning_outcomes.pdf

Olfaz, A. (2019). The foreign language anxiety in learning German and the effects of total physical response method on students' speaking skill. Journal of Language and Linguistic Studies, 15(1), 70-82. Retrieved on March 13, 2021 from: https://www.jlls.org/index.php/jlls/article/view/992/446 
Osada, N. (2004). Listening comprehension research: A brief review of the last thirty years. Dialogue, 3, 53-66.

Plough, I. (2018). Revisiting the speaking construct: The question of instructional competence. Language Testing, 35(3), 325-329. DOI: 10.1177/0265532218772322

Ramanathan, H. (2007). Testing of English in India: A developing concept. Language Testing, 25(1), 111-126. DOI: $10.1177 / 0265532207083747$

Rost, M. (2001). Listening. In R. Carter \& D. Nunan (Eds.), The Cambridge Guide to Teaching English to Speakers of Other Languages (pp. 7-13). Cambridge: Cambridge University Press. DOI: 10.1017/CBO9780511667206.002

Rost, M. (2002). Teaching and researching: Listening (2 $2^{\text {nd }}$ edn.). New York: Routledge.

Rubin, J. (1994). A review of second language listening comprehension research. Modern Language Journal, 78(2), 199-221. DOI: 10.1111/j.1540-4781.1994.tb02034.x

Underwood, M. (1989). Teaching listening. London: Longman.

Vandergrift, L. (2007). Recent development in second language listening comprehension research. Language Teaching, 40(3), 191-210. DOI: 10.1017/S0261444807004338

Vandergrift, L., \& Goh, C. C. M. (2009). Teaching and testing listening comprehension. In M. Long \& C. Doughty (Eds.), The Handbook of Language Teaching (pp. 395-411). Chichester: WileyBlackwell.

Walker, N. (2014). Listening: the most difficult skill to teach. Encuentro, 23, 167-175.

Yagang, F. (1994). Listening: Problems and solutions. In T. Kral (Ed.), Teacher development: Making the right moves (pp. 1-7). Washington, DC: English Language Programs Division, USIA.

Zhang, Y. (2009). An experimental study of the effects of listening on speaking for College Students. English Language Teaching, 2(3), 194-204. Retrieved on February 22, 2021 from: https://files.eric.ed.gov/fulltext/EJ1083054.pdf

\section{AUTHORS BIODATA}

Nida Qayoom has a PhD in English and she has been teaching language and literature for more than a decade. At present, she is working at the English Department, Faculty of Sciences \& Arts, King Abdulaziz University, Rabigh branch in the Kingdom of Saudi Arabia. Her research interests include ELT and Applied Linguistics.

Mohammad Saleem has a PhD in English from the University of Allahabad, India. He has been teaching language and literature for more than a decade. At present, he is working at the English Department, Faculty of Sciences \& Arts, King Abdulaziz University, Rabigh branch in the Kingdom of Saudi Arabia.

Mozaffar Mansoor teaches English at the College of Applied Studies and Community Service, Imam Abdulrahman Bin Faisal University, Dammam, Saudi Arabia. His research interests include ELT, ESP, and Applied Linguistics.

\footnotetext{
${ }^{\mathrm{i}}$ The speaking and listening skill examinations are divided into two parts: a listening examination and a speaking examination. Students take the ASL speaking test in pairs. The examiner needs to audio-record the session for every examination. The test lasts eight minutes for class 9 and ten minutes for class 11 . The listening test is conducted for the whole class, and students record their responses on an answer sheet as the audio clip is played through a public address system. Class 9 ASL conforms to the B1 level of the CEFR, while class 11 ASL conforms to the B2 level of the CEFR. The speaking exam consists of four different stages, namely, Introduction, Topic presentation, Problem-solving task, and Interaction (CBSE, n.d.)
} 